University of Nebraska - Lincoln

DigitalCommons@University of Nebraska - Lincoln

Faculty Papers and Publications in Animal

Science

Animal Science Department

1957

\title{
Protein and Fat Requirements of Baby Pigs
}

E. R. Peo, Jr.

University of Nebraska-Lincoln

G. C. Ashton

Ontario Agricultural College

V. C. Speer

lowa Agricultural Experiment Station

D. V. Catron

lowa Agricultural Experiment Station

Follow this and additional works at: https://digitalcommons.unl.edu/animalscifacpub

Part of the Animal Sciences Commons

Peo, Jr., E. R.; Ashton, G. C.; Speer, V. C.; and Catron, D. V., "Protein and Fat Requirements of Baby Pigs"

(1957). Faculty Papers and Publications in Animal Science. 620.

https://digitalcommons.unl.edu/animalscifacpub/620

This Article is brought to you for free and open access by the Animal Science Department at DigitalCommons@University of Nebraska - Lincoln. It has been accepted for inclusion in Faculty Papers and Publications in Animal Science by an authorized administrator of DigitalCommons@University of Nebraska - Lincoln. 
Journal of Animal Science 16 (1957), pp. 885-891.

Copyright $\odot 1957$ American Society of Animal Science. Used by permission.

\title{
PROTEIN AND FAT REQUIREMENTS OF BABY PIGS ${ }^{1,2}$
}

\author{
E. R. Peo, JR., ${ }^{3}$ G. C. Ashton ${ }^{4}$ V. C. Speer and D. V. Catron \\ Iowa Agricultural Experiment Station ${ }^{5}$
}

PRESENT day research in swine nutrition with its early weaning programs and its use of the baby pig in biological assays has necessitated the determination of the nutritional requirements of the baby pig. The requirements for two of these nutrients (protein and fat) have not been clearly established. Early studies on the protein and fat requirements of baby pigs were conducted with liquid synthetic milk diets, which were formulated generally on the basis of the composition of sow milk.

Reber et al. (1953) fed synthetic milk diets of varying protein and fat levels to baby pigs and observed that at an early age best performance was obtained from pigs fed $41 \%$ protein and $35.7 \%$ fat, but as the pigs approached weaning age ( 56 days) lower levels of protein appeared to be adequate. Sewell et al. (1953) reported that satisfactory results were obtained with synthetic milk diets that contained $24 \%$ and $28 \%$ protein, although the best results were obtained with one containing $32 \%$ protein.

Becker et al. (1954) compared protein levels from 10.2 to $30.6 \%$ for pigs from 1 to 4 weeks of age and from 10 to $25.5 \%$ protein for pigs from 5 to 9 weeks of age, and showed that $22.4 \%$ and $12 \%$ protein diets for the two age groups, respectively, were equal to the higher levels of protein fed. Catron et al. (1953) tested liquid synthetic-milk rations containing 10, 20 or $30 \%$ fat on baby pigs and observed that with a $15 \%$ solids ration, the lowest level of fat $(10 \%)$ produced the best growth.

Speer et al. (1954) developed for early-weaned pigs a dry-pre-starter ration which contained $24 \%$ protein and $7 \%$ fat. Excellent gains were made by the baby pigs fed this ration. Crampton and Ness (1954) reported an experiment with a dry-meal ration for baby pigs in which they compared two levels of protein and two levels of fat. The greatest gains and feed efficiency were made by the pigs fed the diet containing $30 \%$ protein and $8 \%$ fat. Hanson et al. (1954) were not able to show a significant increase in gains or feed efficiency by the addition of $5.1 \%$ of a lard-lecithin mixture to a dry ration for early-weaned baby pigs.

This experiment was conducted to define further the protein and fat requirements of baby pigs fed a dry-meal ration.

\footnotetext{
1 Journal Paper No. J-2964 of the Iowa Agricultural Experiment Station, Ames, Iowa. Project No. 959.

${ }^{2}$ From a portion of a thesis presented by E. R. Peo, Jr., to the Graduate College, Iowa State College, in partial fulfillment of the requirements for the Ph.D. degree, 1956.

3 Present address: Department of Animal Husbandry, University of Nebraska, Lincoln, Nebraska.

4 Present address: Department of Physics, Ontario Agricultural College, Guelph, Canada.

5 Department of Animal Husbandry. Acknowledgement is made to Mr. Don Quinn, Swine Nutrition Research Farm superintendent and his associates for their assistance.
} 


\section{Experimental}

Animals. Two hundred seventy-two crossbred (Duroc $\times$ Landrace $X$ Poland China) baby pigs, weaned at an average weight of $6.4 \mathrm{lb}$. and at an average age of 7.9 days, were used in a $4 \times 4$ factorial plan (see table 4) of a randomized block design. Each of the 16 ration treatments was tested on three pens of four and one pen of five pigs each for a total of 17 pigs per treatment. Limited housing facilities permitted the testing of only one replication of the 16 ration treatments at any one time. The pigs were allotted, as they became available, to the treatments at random within litters within replication.

TABLE 1. COMPOSITION OF BASAL RATION

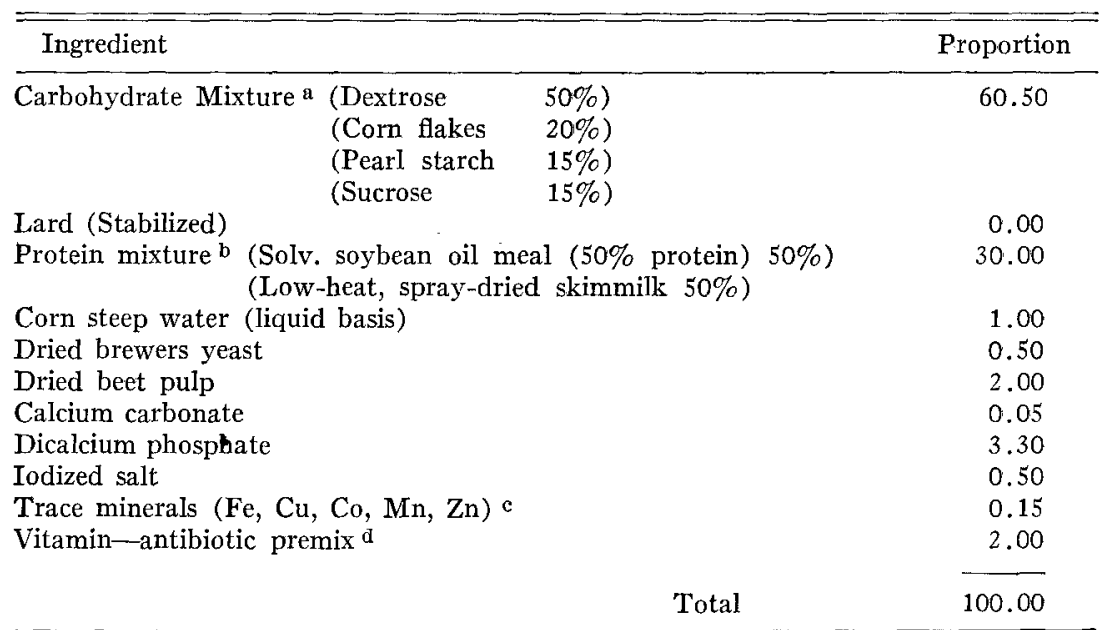

\footnotetext{
a Fat levels developed by substituting stabilized lard for carbohydrate mixture.

b Protein levels developed by varying the proportions of the carbohydrate and protein mixtures.

c Supplied the elements in the following amounts for each $\mathrm{lb}$. of complete ration: Fe, $47.7 \mathrm{mg}$; $\mathrm{Cu}$, $3.3 \mathrm{mg}$.; Co, $1.14 \mathrm{mg}$.; $\mathrm{Mn}, 40.2 \mathrm{mg}$. and $\mathrm{Zn}, 3.0 \mathrm{mg}$.

a Added so that each $\mathrm{lb}$. of complete ration contained the following amounts of vitamins and antibiotics: vitamin A, 5000 I.U.; vitamin D2, 1000 I.U.; riboflavin, $5 \mathrm{mg}$; calcium pantothenate, 10 mg.; niacin, $30 \mathrm{mg.;}$ thiamin, $5 \mathrm{mg}$; choline, $450 \mathrm{mg}$; folic acid, $8 \mathrm{mg}$; pyridoxine, $2 \mathrm{mg}$; alpha tocopherol acetate, $10 \mathrm{mg}$; vitamin $\mathrm{C}, 300 \mathrm{mg}$; PABA, $8 \mathrm{mg} . ;$ vitamin $\mathrm{K}, 1 \mathrm{mg}$; vitamin $\mathrm{B}_{12}, 20$ mcg. and antibiotics, $50 \mathrm{mg}$.
}

The temperature of the experimental building was thermostatically held at $70^{\circ} \mathrm{F}$. when the pigs were one to three weeks of age, and at $65^{\circ} \mathrm{F}$. when they were three to five weeks of age. The pigs were confined to pens that were equipped with self-feeders, automatic water founts and radiantheated concrete floors. Heat lamps were used in each pen to assure adequate floor temperature for the first two-week test period.

Rations. The 16 ration treatments were derived from four levels of protein $(15,20,25$ and $30 \%)$ each fed in combination with four levels of fat $(0,2.5,5$ and $10 \%)$. The composition of the basal ration is presented in table 1 . It contained $15 \%$ protein and no added fat. The calcu- 
TABLE 2. GROSS ENERGY VALUES OF EXPERIMENTAL RATIONS AS DETERMINED WITH THE BOMB CALORIMETER a

\begin{tabular}{ccccc}
\hline & \multicolumn{4}{c}{ Fat levels (\%) } \\
\cline { 2 - 5 } Protein level & 0 & 2.5 & 5 & 10 \\
\hline$\%$ & & \multicolumn{4}{c}{ Kcal./per gm. } \\
15 & 3.92 & 3.98 & 4.05 & 4.18 \\
20 & 3.86 & 4.03 & 4.15 & 4.37 \\
25 & 4.11 & 4.16 & 4.32 & 4.54 \\
30 & 4.10 & 4.18 & 4.31 & 4.52 \\
\hline
\end{tabular}

a Each value is the average of duplicate samples.

lated fat content was $0.45 \%$. The protein was supplied by a mixture of equal proportions of solvent soybean oil meal (50\% protein) and low-heat, spray-dried skimmilk (34\% protein). Stabilized lard was used as the source of fat. The gross energy values of the experimental rations as determined by the bomb calorimeter are presented in table 2 . The pigs were fed the experimental rations and remained on test for 28 days.

Analysis of the data. The data were analyzed statistically using the pen of pigs as the experimental unit and the average pig response as the observation. The analysis of variance scheme and a summary of the mean squares for gains and feed efficiencies are presented in table 3. All statements concerning statistical significance of ration treatment effects are at a probability level of $5 \%$ or less.

TABLE 3. ANALYSIS OF VARIANCE FOR GAIN AND FEED PER POUND OF GAIN

\begin{tabular}{|c|c|c|c|c|c|}
\hline \multirow[b]{3}{*}{ Source of variation } & \multirow{3}{*}{$\begin{array}{c}\text { Degrees of } \\
\text { freedom }\end{array}$} & \multicolumn{4}{|c|}{ Mean squares } \\
\hline & & \multicolumn{2}{|c|}{ Two-weeks } & \multicolumn{2}{|c|}{ Four-weeks } \\
\hline & & Gain & $\mathrm{F} / \mathrm{G}$ & Gain & $\mathrm{F} / \mathrm{G}$ \\
\hline Replications & 3 & 3.6167 & 0.6513 & 69.6777 & 0.7785 \\
\hline Fat levels & 3 & & & & \\
\hline Linear regression component & 1 & 1.0588 & 1.4055 & 7.9325 & 0.0007 \\
\hline Quadratic regression component & 1 & 0.0114 & 0.7782 & 1.5250 & 0.0052 \\
\hline Cubic regression component & 1 & 0.1228 & 0.0126 & 0.6841 & 0.0889 \\
\hline Protein levels & 3 & & & & \\
\hline Linear regression component & 1 & 12.2070 & 7.8344 & 20.6553 & 1.2550 \\
\hline Quadratic regression component & 1 & 2.2877 & 2.0556 & 16.9127 & 0.3108 \\
\hline Cubic regression component & 1 & 2.5353 & 0.2935 & 27.0820 & 0.0714 \\
\hline Fat levels $x$ protein levels & 9 & 0.3300 & 0.2210 & 4.0802 & 0.0419 \\
\hline Experimental error & 45 & 0.6041 & 0.2376 & 3.3642 & 0.0353 \\
\hline Total & 63 & & & & \\
\hline
\end{tabular}




\section{Results and Discussion}

In the analysis of the data the mean squares for the interactions ( 9 degrees of freedom, table 3 ) of the protein and fat effects on gain and feed required per pound of gain were tested against the error mean squares for statistical significance. Also the sum of squares for the 9 degrees of freedom associated with these interactions were subdivided into individual component parts (protein linear $\times$ fat linear, etc.) and tested against the error mean squares. None of the " $F$ " ratios obtained were significant thus the data are discussed mainly in terms of main effects (protein and fat) rather than in terms of interactions.

TABLE 4. FIRST TWO-WEEK TEST PERIOD. GAIN AND FEED EFFICIENCIES FOR BABY PIGS FED RATIONS VARYING IN LEVELS OF PROTEIN AND FAT (LB. PER PIG)

\begin{tabular}{|c|c|c|c|c|c|c|}
\hline \multirow[b]{2}{*}{ Items } & \multirow[b]{2}{*}{ Protein level } & \multicolumn{4}{|c|}{ Fat levels $(\%)$} & \multirow[b]{2}{*}{ (Av.) } \\
\hline & & 0 & 2.5 & 5 & 10 & \\
\hline \multirow{6}{*}{ Gain } & $\%$ & & & & & \\
\hline & 15 & $2.95^{a}$ & 3.30 & 2.75 & 2.48 & 2.87 \\
\hline & 20 & 3.90 & 4.10 & 4.20 & 3.78 & 3.99 \\
\hline & 25 & 4.18 & 3.62 & 3.92 & 3.68 & 3.85 \\
\hline & 30 & 4.48 & 4.40 & 3.70 & 4.30 & 4.22 \\
\hline & Av. & 3.88 & 3.85 & 3.64 & 3.56 & \\
\hline \multirow{6}{*}{ Feed/lb. gain } & & & & & & $(\text { Av. })^{c}$ \\
\hline & 15 & 2.33 & 2.52 & 3.20 & 3.30 & 2.84 \\
\hline & 20 & 1.82 & 2.12 & 1.99 & 2.26 & 2.05 \\
\hline & 25 & 1.68 & 2.06 & 2.05 & 1.86 & 1.91 \\
\hline & 30 & 1.64 & 1.84 & 2.12 & 1.75 & 1.34 \\
\hline & Av.d & 1.87 & 2.13 & 2.34 & 2.36 & \\
\hline
\end{tabular}

a These values are averages for 17 pigs.

b Protein cubic regression significant at $\mathrm{P}=0.05$ or less.

e Protein quadratic regression significant at $\mathrm{P}=0.05$ or less.

d Fat linear regression significant at $P=0.05$ or less.

\section{First Two-Week Test Period}

Summaries of the gain and feed efficiency data for this period are presented in table 4.

Gains. On the average, as the protein levels were increased the greater gains observed in the pigs were statistically significant. A statistically significant cubic regression component indicates that the depression of gains at the $25 \%$ protein level is not just a chance result. When the average feed consumption data are considered (feed per gain $X$ gain, table 4), they show that at this level of protein the pigs on $2.5,5$ and $10 \%$ fat failed to consume as much feed as the pigs fed the corresponding fat levels with the $20 \%$ level of protein. While this may be partially responsible for the reduced gains on the $25 \%$ level of protein, the authors are unable 
to offer a plausible explanation for this decreased feed intake which was fairly consistent over the four replications. This consistency suggests that some factor other than chance was responsible for the decreased feed intake. The observation that the $30 \%$ protein rations produced fastest gains is in agreement with the work of Reber et al. (1953) and Becker et al. (1954) which showed that, initially, the protein requirement of the baby pig is high.

The inverse relationship observed between level of fat in the ration and gains (averaged across all levels of protein) was not statistically significant. Certainly the inclusion of 5 or $10 \%$ fat in the rations did not improve gains over the zero percent fat level. As mentioned previously, the zero percent fat rations were calculated to contain $0.45 \%$ fat, a level which, according to the work of Shrewsbury and Vestal (1946) with older pigs, should be limiting. However, in this experiment the only drawbacks encountered with the rations containing zero percent fat were dustiness of the feed and encrustation of the pigs' hair coat with feed particles. These drawbacks were eliminated when the fat level in the ration was $2.5 \%$ or above.

Feed per $l b$. gain. The feed utilization improved markedly as the protein in the ration was increased from 15 to $20 \%$, and continued to improve at a decreasing rate as the protein was increased to $30 \%$ with the result that the quaratic regression component was statistically signficant. In contrast to this, and perhaps contrary to what might be expected, the feed efficiencies decreased as the level of fat was increased in the rations. When averaged across all protein levels, this depressing effect on feed utilization was statistically significant.

Thus, considering both gain and feed efficiency, the data of table 4 show that the combination of the highest level of protein and the lowest level of fat produced the best results for the two-week test period.

\section{Four-Week Test Period}

The four-week gain and feed efficiency data are presented in table 5 .

Gains. The gains of the pigs fed that $15 \%$ protein rations were less than those of the pigs fed $30 \%$ protein, for all four levels of fat. When considering the fat levels individually, gains on 2.5 and $5 \%$ fat increased as the protein level of the ration increased from 15 to $20 \%$. Further increases in protein resulted in decreased gains with these levels of fat. In contrast to this, maximum gains were observed on zero and $10 \%$ fat at the $30 \%$ level of protein. However, this apparent protein $\times$ fat interaction was not statistically significant.

There was a depression in the gain curves of the pigs fed these levels of fat (zero and $10 \%$ ) at the $25 \%$ protein level. These two depressions were of sufficient magnitude that when the gains were averaged across all fat levels, the value of $13.8 \mathrm{lb}$. gain at the $25 \%$ protein level was a 
statistically significant departure from a quadratic response of gain to protein level. For the entire test period, the greatest gains were made by the pigs fed $20 \%$ protein with $2.5 \%$ fat. However, when considering the overall averages of fat and protein, gains were maximum on zero percent fat $(14.2 \mathrm{lb}$.$) and 20 \%$ protein $(15.0 \mathrm{lb}$.

Feed per $l b$. gain. When the values for feed required per $\mathrm{lb}$. of gain were averaged across all fat levels, the observed responses showed a marked increase in feed efficiency when the protein in the ration was increased from 15 to $20 \%$. The feed efficiency remained fairly constant, however, with

TABLE 5. FOUR-WEEK TEST PERIOD. GAIN AND FEED EFFICIENCIES FOR BABY PIGS FED RATIONS VARYING IN LEVELS OF PROTEIN AND FAT (LB. PER PIG)

\begin{tabular}{|c|c|c|c|c|c|c|}
\hline \multirow[b]{2}{*}{ Items } & \multirow[b]{2}{*}{ Protein level } & \multicolumn{4}{|c|}{ Fat levels $(\%)$} & \multirow[b]{2}{*}{$A v .^{b}$} \\
\hline & & 0 & 2.5 & 5 & 10 & \\
\hline \multirow{6}{*}{ Gain } & $\%$ & & & & & \\
\hline & 15 & $13.10^{\mathrm{a}}$ & 12.97 & 12.62 & 10.70 & 12.35 \\
\hline & 20 & 14.92 & 16.05 & 15.35 & 13.87 & 15.05 \\
\hline & 25 & 13.67 & 13.87 & 14.85 & 12.85 & 13.81 \\
\hline & 30 & 15.17 & 13.25 & 13.87 & 15.52 & 14.45 \\
\hline & Av. & 14.21 & 14.03 & 14.17 & 13.23 & \\
\hline \multirow{6}{*}{ Feed/lb. gain } & & & & & & $A v .^{c}$ \\
\hline & 15 & 2.06 & 2.16 & 1.99 & 2.20 & 2.11 \\
\hline & 20 & 1.77 & 1.81 & 1.69 & 1.86 & 1.78 \\
\hline & 25 & 1.76 & 1.67 & 1.74 & 1.82 & 1.75 \\
\hline & 30 & 1.69 & 1.89 & 1.69 & 1.53 & 1.70 \\
\hline & Av. & 1.82 & 1.88 & 1.78 & 1.85 & \\
\hline
\end{tabular}

a These values are averages for 17 pigs.

b Protein cubic regression significant at $P=0,05$ or less

c Protein quadratic regression significant at $\mathrm{P}=0.05$ or less.

further increases in the protein level. This quadratic response was statistically significant. On the average, there was little effect of fat levels on feed efficiency.

\section{Summary}

Four protein and four fat levels were studied in a $4 \times 4$ factorial experiment with 272 baby pigs fed dry-meal rations to determine the effect of protein and fat levels on gains and feed efficiency.

Response to protein levels $(15,20,25$ or $30 \%)$ for the first two-week test period showed a significant linear regression with maximum gains occurring on $30 \%$ protein. For the four-week test period, the observed gains when averaged across all fat levels $(0,2.5,5.0$ and $10 \%)$ reached a maximum on the $20 \%$ protein rations.

There was no significant difference in gains attributable to fat levels 
for either the first two-week or the four-week test period. However, when fat was added to the rations, the appearance of the pigs was improved. Fat also improved the physical characteristics of the ration.

Feed efficiency was significantly improved by increasing protein levels for both the first two-week and the four-week test periods. With increasing levels of fat, a significant linear decrease in feed efficiency occurred for the first two-week test period, but there was no significant difference in feed efficiency due to fat for the four-week test period.

\section{Literature Cited}

Becker, D. E., D. E. Ullrey and S. W. Terrill. 1954. Protein and amino acid intakes for optimum growth rate in the young pig. J. Animal Sci. 13:346.

Catron, D. V., Leroy F. Nelson, Gordon C. Ashton and Helen M. Maddock. 1953. Development of practical synthetic milk formulas for baby pigs. J. Animal Sci. $12: 62$.

Crampton, E. W. and O. M. Ness. 1954. A meal mixture suitable as the entire ration to be self-fed dry to pigs weaned at ten days of age. J. Animal Sci. 13:357.

Hanson, L. E., E. A. Rutledge, J. M. Russo and E. F. Ferrin. 1954. Dry rations for pigs weaned at 3 weeks. Minn. 32nd Annual Swine Feeder's Day Report.

Reber, Elwood F., C. K. Whitehair and Robert MacVicar. 1953. The effects of level of protein fed baby pigs. J. Nutr. 50:451.

Sewell, R. F., B. E. Sheffey, R. G. Eggert and J. K. Loosli. 1953. Studies on the protein requirements of suckling pigs. J. Animal Sci. 12:597.

Shrewsbury, C. L. and C. M. Vestal. 1946. The role of fat in swine nutrition with special reference to factors affecting the quality of pork. Fifty-ninth Rpt. of the Director, Purdue Univ. Agr. Exp. Sta.

Speer, Vaughn C., Gordon Ashton, Francis Diaz and Damon Catron. 1954. New I.S.C. Pre-Starter "75". Iowa Farm Sci. 8:3. 